\title{
Anthropometry, Fatty Liver, Plasma Lipid, and Adipose Tissue on Rat Wistar Induced Low-Protein Diet
}

Dian Handayani*, Inggita Kusumastuty, Kanthi Permaningtyas Tritisari, Laily Ekawati Candra, Glaveria Galuh Giriananda, Lailatul Muniro, Lega Satya Puspitasari, Ratih Indah, Anis Mahmudah

Department of Health and Nutrition, Faculty of Medicine, Brawijaya University, Malang, Indonesia

\section{ABSTRACT}

Protein energy malnutrition problem still exists in developing country. In fact, Indonesia has faced it as double burden of nutrition problems. This study aims to develop a standardized diet for developing protein energy malnutrition (PEM) on the rat to support nutrition research. Low-protein modified AIM-93M diet (LP) has been given to rats for 12 weeks intervention compared to normal protein diet (ND). Anthropometry, plasma lipid, fatty liver and the weight of adipose tissue have been analysed. The LP group showed a significantly lower body weight, body length and waist circumference $(\mathrm{p}<0.05)$, a more fatty liver marker shown in LP compared to $\mathrm{ND}(\mathrm{p}<0.05)$. This study suggests that giving low protein modified AIN-M93 diet promotes protein energy malnutrition in the rat.

Keywords: Protein nergy malnutrition (PEM), low protein diet, anthropometry, fatty liver

\section{INTRODUCTION}

Energy protein deficiency is a fundamental nutrition problem in developing country including Indonesia. Some studies in the clinical setting have been conducted to identify the problem of energy protein deficiency $[1,2,3,4]$. Nowadays, the functional food research for combating PEM is demanding. However, there are some limitations of clinical studies for proving the effect of functional food combating PEM. Several ethical and pragmatic constraints associated with using human subjects, while animal experiments are reproducible and robust. Therefore using the animal model as research sample for nutrition intervention is the main concern. For this purpose, the animal model needs a standardized diet to minimize variation during an experiment that resulted from the diet in an animal model [5]. Standardized diet for an animal model, especially rat, is AIN-93M [5] using for the maintenance of growth of rat as an animal model. However, others researcher also use other standard diets such as PARS for maintaining animal model growth.

This project aims to develop low energy protein diet standard that is modified from AIN-93M. Thus this study will examine the effects of low protein diet ${ }^{*}$ Corresponding author:

Dian Handayani

Department of Health and Nutrition, Faculty of Medicine, Brawijaya University

Jalan Veteran, Malang, Indonesia 65162

E-mail: dian_handayani@ub.ac.id on the anthropometry, fatty liver, plasma lipid, and adipose tissue. As an effect of PEM is lowering anthropometry size, developing fatty liver, changing in plasma lipid level and the loss the adipose tissue fat mass in body weight.

\section{MATERIALS AND METHODS \\ Animals and housing condition}

The Ethical committee for Conduction of Animal Studies at Faculty of Medicine, University of Brawijaya (UB) approved the experimental protocol (No. 416/EC/KEPK/07/2014). The animals in these experimental protocols were individually housed in cages.

\section{Animals and diet}

Thirty-two male Wistar rats, weighing 177-259 g at \pm 3 months. All rats were fed in the Brawijaya University laboratory non-purified diet (PARS) during the acclimatization period. Then, thirty-two rats were divided into two groups $(n=16)$. The first group was continuously given PARS (Wonokoyo, Indonesia) as normal diet (ND) and the second group was given low-protein modified AIN-93M modified (LP). The dietary intervention was carried out addlibitum for twelve weeks.

\section{How to cite:}

Handayani D, Kusumastuty I, Tritisari KP et al. (2017)

Anthropometry, Fatty Liver, Plasma Lipid, and Adipose Tissue on Rat Wistar Induced Low-Protein Diet. J. Trop. Life. Science $7(1): 48-52$. 
Table 1. Percentage of nutrient in PARS (ND) and AIN-93M $\operatorname{diet}(\mathrm{LP})$

\begin{tabular}{lcc}
\hline Nutrient Percentage & PARS (ND) & Modified AIN-93 M(LP) \\
\hline Carbohydrate & $75.1 \%$ & $77.66 \%$ \\
Fat & $4.78 \%$ & $11.21 \%$ \\
Protein & $15.14 \%$ & $8.07 \%$ \\
Energy density & $2.22 \%$ & $3.2 \%$ \\
\hline
\end{tabular}

Nutrients composition of both diets are illustrated by Table 1.

\section{Food intake}

Food intake was measured every 24 hours by weighing the amount of total food ( $\mathrm{g}$ ) provided to the rats and subtracting the remaining food $(\mathrm{g})$ in the cage after 24 hours.

\section{Anthropometric, plasma lipid, white adipose tissue, and fatty liver analysis}

Following the intervention period, Rat was anesthetized and killed by ketamine and xylazine 0.005 $\mathrm{mL} / \mathrm{g}$ body weight via intramuscular rats. The anthropometric measurement including body weight was weighed weekly throughout the twelve-week intervention period. Others anthropometric measurement are abdominal circumference (AC), thoracic circumference (TC), body length (nose to-anus or anus-to-nose length) were made in anesthetized rat

The white adipose tissue (WAT) comprised visceral fat (epididymal, perirenal, and omental fat) and subcutaneous fat (inguinal fat) were then dissected out and weighed. Plasma samples were obtained by puncturing the right ventricle of heart after euthanasia and were collected in ethylenediaminetetraacetic acid- (EDTA-) coated tubes and centrifuged at $3000 \times \mathrm{rpm}$ at $22^{\circ} \mathrm{C}$ for 25 minutes [6]. The whole liver was quickly removed, placed in formalin, and then stored at $-20^{\circ} \mathrm{C}$ until it was analyzed. We examined the liver lipid accumulation using Hematoxylin-Eosin (HE)-stained as modified from previous protocol described previously $[7,8]$

\section{RESULTS AND DISCUSSION}

\section{Food intake, body weight, AC, TC and body length}

PARS (ND) was given to the rats as a control group (normal diet), and Low protein modified AINM93 diet had been given to rat with ad libitum or as desired. In adaptation phase, every rat had been given PARS diet, but slowly rat in LP was given low-protein modified AIN-93 $\mathrm{M}$ diet aiming to adjust the rat with treatment during research. After adaptation phase (2
Table 2. Anthropometry and nutrient intake

\begin{tabular}{lccc}
\hline \multicolumn{1}{c}{ Treatment group } & $N D$ & $L P$ & p-value \\
\hline Baseline body weight $(\mathrm{g})$ & $204.03 \pm 16.65$ & $210.18 \pm 19.95$ & 0.35 \\
Final body weight $(\mathrm{g})$ & $362.71 \pm 41.35$ & $149.50 \pm 18.17$ & 0.00 \\
Body weight gain $(\mathrm{g})$ & $165.31 \pm 40.75$ & $-60.69 \pm 15.74$ & 0.00 \\
Body length $(\mathrm{cm})$ & $25.44 \pm 0.78$ & $21.31 \pm 1.11$ & 0.00 \\
TC $(\mathrm{cm})$ & $15.9 \pm 1.06$ & $11.72 \pm 0.81$ & 0.00 \\
AC $(\mathrm{cm})$ & $17.50 \pm 1.34$ & $13.29 \pm 0.98$ & 0.00 \\
Food intake $(\mathrm{g})$ & $41.26 \pm 5.51$ & $11.34 \pm 1.57$ & 0.00 \\
Energy $(\mathrm{kcal})$ & $96.5 \pm 12.89$ & $38 \pm 5.27$ & 0.00 \\
Protein $(\%)$ & 15.13 & 8.07 & 0.00 \\
Fat $(\%)$ & 4.77 & 11.2 & 0.111 \\
Carbohydrate $(\%)$ & 75.11 & 77.66 & 0.00 \\
\hline
\end{tabular}

Note: Amount (n) = 16 samples, ND = PARS Normal Diet, LP = Low Protein modified AIN-93M Diet; TC (thoracic circumference); AC (abdominal circumference)

weeks), PARS normal diet was still given to ND rat, but LP was given low protein modified AIN-93M.

Table 2 showed that rat in PARS normal diet group (ND) encounters a weight gain (165.31 \pm 40.75). Meanwhile, a rat in AIN-93 M normal diet standard encounters a weight loss $(-60.69 \pm 15.74)$. Similar result is shown in body length, AC, and TC; LP group was significantly lower than ND group, $\mathrm{p}=0.00(\alpha=$ 0.05).

Rat intake was measured by reducing the given food amount with food leftover that was weighed every day. Then, rat intake was converted into energy value, carbohydrate, protein, and fat for each diet. Intake average, energy total, carbohydrate, protein, and fat can be seen in Table 2 .

The food intake in ND group $(41.26 \pm 5.51) \mathrm{g}$ is higher than intake average in LP $(11.34 \pm 1.57) \mathrm{g}$ with p-value $0.00(\alpha=0.05)$. Thus, energy average in ND $(96.5 \pm 12.89) \mathrm{Kcal} /$ day is higher than LP $(38 \pm 5.27)$ $\mathrm{Kcal} /$ day with $\mathrm{p}$-value $0.00(\alpha=0.05)$. This result revealed a significant difference between energy and food intake in ND and LP. It showed that rat consumed low protein modified AIN-93 diet less than PARS.

Factor that can affect rat intake is energy density and also percentage of fat from the total energy. Rat intake in LP is significantly lower than ND. It is because energy density in LP is higher than ND. A higher energy density caused the rat to feel fullness faster, so it reduces rat consumption [9]. Fat intake in ND contributes $4.77 \%$ of total energy. Meanwhile, fat intake LP contributes $11.2 \%$ of total energy. There is no significant difference in fat intake with $\mathrm{p}$-value 0.11 
Table 3. Plasma lipid and body fat mass

\begin{tabular}{lccc}
\hline \multicolumn{1}{c}{ Plasma } & $N D(\mathrm{mg} / \mathrm{dL})$ & $L P(\mathrm{mg} / \mathrm{dL})$ & $p$-value \\
\hline Cholesterol & $70.69 \pm 15.93$ & $65.50 \pm 15.98$ & 0.37 \\
Triglyceride & $74.88 \pm 34.20$ & $47.44 \pm 27.09$ & 0.01 \\
LDL & $25,08 \pm 15.38$ & $24.65 \pm 6.61$ & 0.53 \\
HDL & $49.04 \pm 9.01$ & $43.07 \pm 9.13$ & 0.07 \\
White Adipose Tissue & $19.42 \pm 5.48$ & $2.59 \pm 0.87$ & 0.00 \\
Fatty liver & $4.23 \pm 2.15$ & $35.36 \pm 19.59$ & 0.00 \\
\hline
\end{tabular}

$(\alpha=0.05)$. It has been reported that high-fat-dietinduced satiety effect longer than normal fat content diet. Thus it decreases food intake.

Carbohydrate intake in ND contributes $75.11 \%$ of total energy. Meanwhile, carbohydrate intake in LP contributes $77.66 \%$ of total energy. There is a significant difference in carbohydrate intake with $\mathrm{p}$-value 0.00 $(\alpha=0.05)$. It also becomes a reason that consumption in LP is lesser than ND. The higher carbohydrate content in diet can make rat feel full faster, so food intake in LP is lower than ND. A high glucose can stimulate satiety center that is located in the ventromedial nucleus of the hypothalamus and otherwise, a lower glucose, can stimulate neuron in feeding center that is located in the lateral nucleus of the hypothalamus. Stimulation in feeding center increases hunger. Satiety center affects the incidence of satiety after eating. This feeling of satiety due to the increase in blood glucose after we eat causes the increasing glucose that passes through satiety center and activates it [10].

Protein intake in ND contributes $15.13 \%$ of total energy. Meanwhile, protein intake in LP contributes $8.07 \%$ of total energy. There is a significant difference in protein intake with $\mathrm{p}$-value $0.00(\alpha=0.05)$. The recommendation of protein content on rat feed is $14.1 \%$. It is to fulfill rat protein requirement for maintenance their health [5]. LP group contains 8.07\% protein, and the other hand ND provides $15 \%$ protein from total energy. The difference of protein content affects on total daily food intake of the rat. ND group consumed more food than LP group. This shows that mice did not well accept LP diet.

Malta et al. and de Oliveira et al. [11, 12] reported that low protein diet ( $4 \%$ total energy) on rat decreased food intake compared to normal protein diet on a rat. The Impact of decreased intake in that research is similar to this research. In this research, the total protein is $8 \%$ from total energy, which still contains too low protein in rat food. Both studies showed the decreasing food intake affects weight gain during the administration of low protein diet. Study from Malta et al. and de Oliveira et al. revealed, 30 days low protein diet on rat induces hyperleptinemia thus decreases food appetite on rat $[11,12]$.

\section{Plasma lipid and body fat mass}

Rat plasma cholesterol, triglyceride, Low-Density Lipoprotein (LDL), High-Density Lipoprotein (HDL), and white adipose tissue (WAT) were analysed after 12 weeks treatment. Table 3 shows the result of those variables (plasma lipid, body fat mass, and foam cell).

Table 3 shows mean \pm standard deviation for each variable. There is no significance different in cholesterol total, LDL, and HDL with a p-value in sequence $0.37,0.53$, and 0.07 . For triglyceride there is a significance different between ND $(74.86 \pm 34.20)$ and LP $(47.44 \pm 27.10)$ with $p$-value $0.01(\alpha=0.05)$. This difference caused by different intake in each group. Whereas, intake in ND diet is higher than low-protein modified AIN-93M.

PARS diet is made from comfeed PARS whose contains Distillers Dried Grains with Soluble (DDGS) and feed addictive that stimulate growth process in chicken so if it is given to animal model it can stimulate their appetite [13]. In this research, a higher intake possibly was caused by comfeed content, and it can cause triglyceride serum in an animal model.

WAT total amount was measured by weighing some part in rat such as perinatal, omental, epididymal, and inguinal. Table 4 shows that WAT in ND $(19.42 \pm 5.48 \mathrm{~g})$ is higher than LP $(2.60 \pm 0.87 \mathrm{~g})$ with $\mathrm{p}$-value 0.00 . It means that there is a significant difference in WAT between ND and LP $(\alpha=0.05)$.

Meanwhile, in ND group there was an excessive energy, so it was used to increase adipose tissue mass. Moreover, a fat source in LP comes from soy fat with high polyunsaturated fatty acids (PUFA). PUFA in diet can obstruct lipogenesis in the liver. Meanwhile, in ND one of the fat sources is Distiller's Dried Grains with Soluble (DDGS) which have high saturated fatty acid.

In this research, food intake in ND is higher than LP. It was the reason why a total of WAT from four places (perirenal, omental, epididymal, and inguinal) in ND is greater than LP. The lower intake in LP causes fat that has been used as energy source, meanwhile in $\mathrm{ND}$, there is an excessive energy that used to increase e adipose tissue mass. This statement supported by Fantuzzi and Mazzone (2007), stating that the higher rat intake, the amount of excess energy will be higher, so it will be deposited in TAG form in adipose tissue that contributes in WAT enlargement. However, in energy deficiency TAG in adipose tissue will be broken down 


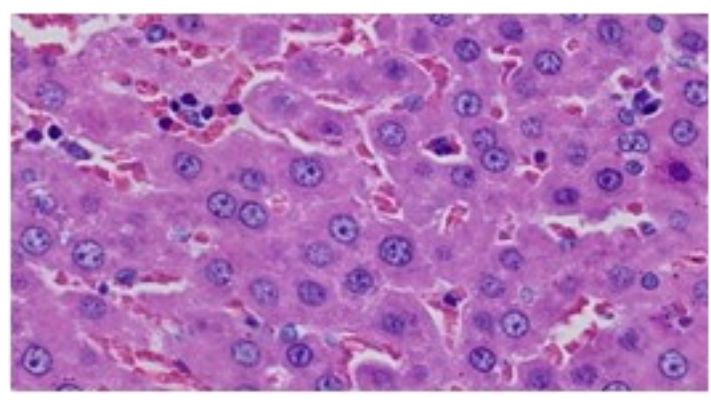

(a)

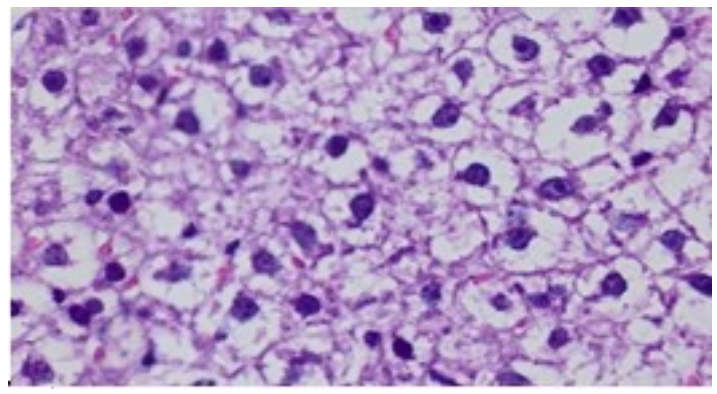

(b)

Figure 1. The effect of the different protein composition diet on lipid droplet deposition of hepatic tissue by HE staining, observed by microscope Olympus photo slide BX51 with 400× magnification.

into fatty acid that will be used as energy source by another organ [14]. It can be concluded that adipose cell enlargement results from imbalanced lipogenesis and lipolysis [15].

\section{Fatty liver}

ND and LP rat's liver cell can be seen in Figure 1 and there is different in hepatic tissue ND (A) and LP (B). In picture A there are a lot of normal cell. Meanwhile, in picture B liver cell has experienced intracytoplasmic swelling that pressing nucleus position, causing nucleus position in peripheral. As we seen in Table 3 , the amount of fatty liver cell in LP is higher than ND with p-value $0.00(\alpha=0.05)$.

Lower food intake and protein intake in the rat have an effect on weight loss. It makes rat in kwashiorkor condition lead to fatty liver in rats. Rats in kwashiorkor condition will increase fatty acid serum level and low Very Low-Density Lipoprotein (VLDL) level [16]. The low VLDL level was resulted from low intake amino acid, so it makes Apoprotein B-100 and Apoprotein C synthesis decrease. The low VLDL causes the transport failure of triglyceride from the liver to tissue. This causes an excessive accumulation of fat in the liver, well known as fatty liver [17].

\section{CONCLUSION}

In conclusion, It has been shown that low-protein administration modified from AIN-93M standard diet develops protein energy malnutrition that mimics developing human PEM reflected from the changes of anthropometry parameters, fatty liver, plasma lipid and adipose tissue.

\section{ACKNOWLEDGMENT}

All student from nutrition department, medicine faculty, University of Brawijaya that part of this research group. This research was supported by Medicine Faculty research funding 2015.

\section{REFERENCES}

1. Fouque D, Kalantar-Zadeh K, Kopple J et al (2008) A proposed nomenclature and diagnostic. Kidney International 73 (4): 391-398. doi: 10.1038/sj.ki.5002585.

2. Gurung G (2010) Social determinants of protein-energy malnutrition: need to attack the causes of the causes. Journal of Health, Population, and Nutrition 28 (3): 308-309.

3. Purwestri RC, Scherbaum S, Inayati DA et al (2013) Impact of daily versus weekly supply of locally produced ready-to-use food on growth of moderately wasted children on Nias island, Indonesia. ISRN Nutrition 2013 (2013): 1-10. doi: 10.5402/2013/412145.

4. Burchi F, Fanzo F, Frison E (2011) The role of food and nutrition system approaches in tackling hidden hunger. International Journal of Environmental Research and Public Health 8 (2): 358-373. doi: 10.3390/ijerph8020358.

5. Reeves PG (1993) AIN-93 purified diets for laboratory rodents: final report of the American institute of nutrition ad hoc writing committee on the reformulation of the AIN-76A rodent diet. The Journal of Nutrition 123 (11): 1939-1951.

6. Riesanti D, Masiana C, Herawati (2012) Kadar HDL, kadar LDL dan gambaran histopatologi aorta pada hewan model tikus (Rattus novergicus) hiperkolsterolemia dengan terapi ekstrak air benalu mangga (Dendrophthoe pentandra). Undergraduate Final Assignment. Brawijaya University, Veterinary Department.

7. Kudo T, Tamagawa T, Kawashima M et al. (2007) Attenuating effect of clock mutation on tryglyceride contents in the ICR mouse liver under a high high-fat diet. Journal of Biological Rhythms 22: 312-323. doi: 10.1177/0748730407302625.

8. Perhimpunan Dokter Spesialis Patologi Indonesia(2008) Pedoman Penanganan Bahan Pemeriksaan untuk Histologi. Jakarta, PT Roche Indonesia.

9. Rolls B (2000) The role of energy density in the over-consumption of fat. American Society for Nutritional Sciences 
130 (2S Suppl): 268S-271S.

10. Muhammad I (2011) Manajemen Pemeliharaan Ayam Petelur di CV. Sari Makmur Farm Kabupaten Sukoharjo. Surakarta, Universitas Sebelas Maret.

11. Malta A, de Oliveira JC, Ribeiro TA et al. (2014) Low-protein diet in adult male rats has long-term effects on metabolism. Journal of Endocrinology 221: 285-295. doi: 10.1530/JOE-13-0473.

12. de Oliveira JC, Lisboa PC, de Moura EG et al. (2013) Poor pubertal protein nutrition disturbs glucose-induced insulin secretion process in pancreatic islets and programs rats in adulthood to increase fat accumulation. Journal of Endocrinology 216 (2): 195-206. doi: 10.1530/JOE-12-0408

13. Tangendjaja B (2008) Distiller's Dried Grains With Solubles (DDGS) untuk pakan. Wartazoa: Buletin Ilmu Pe- ternakan Indonesia 18: 137-148.

14. Ahmadian M, Duncan RE, Sul SH (2008) Triacylglycerol metabolism in adipose tissue. Future Lipidol 2 (2): 229237. doi:10.2217/17460875.2.2.229.

15. MacKay H, Khazall R, Patterson ZR et al. (2013) Rats perinatally exposed to food restriction and high-fat diet show differences in adipose tissue gene expression under chronic caloric restriction. Adipocyte 2 (4): 237-245. doi: 10.4161/adip. 24752.

16. Leon (1993) Disease of the liver volume 7. Philadelphia, B Lippincott Company.

17. Kneeman JM, Misdraji J, Corey KE (2012) Secondary causes of nonalcoholic fatty liver disease. Therapeutic Advances in Gastroenterology 5 (3): 199-207. doi: 10.1177/1756283X11430859. 